\title{
Isolation and Characterization of Bacterial Endophytes From Lycopersicon esculentum Plant and Their Plant Growth Promoting Characteristics
}

\author{
Hardik A. Patel ${ }^{1}$, Rajesh K. Patel ${ }^{1 *}$, Sunil M. Khristi ${ }^{1}$, Kruti Parikh ${ }^{1}$, Geetha Rajendran ${ }^{2}$ \\ ${ }^{1}$ Ashok \& Rita Patel Institute of Integrated Study and Research in Biotechnology and Allied Sciences (ARIBAS), New Vallabh \\ Vidyanagar, Gujarat-388121, INDIA \\ ${ }^{2}$ Sultan Qaboos University, Muscat, Department of Biology, Sultanate of Oman
}

Corresponding author: rkpate146@yahoo.com

\begin{abstract}
The study was designed to isolate and characterize bacterial endophytes from root and stem of Lycopersicon esculentum plant which was collected form different region of Gujarat. Total 18 isolates of endophytic bacteria were selected in which, all the endophytic bacteria produced one or the other different characteristics involved in plant growth promotion. They either produced phytohormones like indole acetic acid, siderophore, protease, pectinase, organic acid showed antifungal activity, chromium tolerance and solubilized phosphate. Four of the strains among the 18 showed maximum positive results of plant growth promoting regulators (PGPR) test and among them best probable isolate was selected and thus its 16SrDNA was amplified and sequenced. Only HR7 endophyte of tomato turned out to be Pseudomonas aeruginosa. It's a gram negative coccobacili, sporeforming motile bacilli and show maximum PGPR activity. The results of our present studies indicated that above strains might be endophytic and therefore, were associated with the plant growth.
\end{abstract}

Keywords: Lycopersicon esculentum, endophytic bacteria, PGPR, IAA, 16SrDNA

\section{Introduction}

There are many endophytic and epiphytic bacteria are directly or indirectly involved in plant growth and development. Endophytic bacteria live in plant tissues without causing substantive harm to the host or gaining any benefit other than a noncompetitive environment inside the host. It has recently been demonstrated that bacterial endophytes may also have beneficial effects on host plants, such as growth promotion and biological control of pathogens $[10,25,28]$. 
Some studies have indicated that the plant growth-promoting potential of endophytes is higher than that of rhizosphere microbes [23,31], but the role of bacterial endophytes in plant growth are not yet fully understood. Most of these microorganisms are not pathogenic to the host plant. Moreover, the association between the plant and its endophytes is very often mutualistic. In 1926, endophytic growth was recognized as a particular stage in the life of bacteria, described as an advanced stage if infection and as having a close relationship with mutualistic symbiosis [22]. Since then, endophytes have been defined as microorganisms that could be isolated form surface-sterilized plant organ [15]. Although the presence of bacterial endophytes in plants is variable and, occasionally transient [32], they are also often capable of eliciting drastic physiological changes that modulate the growth and development in the plant [8].

The utilization of endophytic and epiphytic bacteria in agriculture production depends on our knowledge of the bacteria-plant interaction and our ability to maintain, manipulate and modify beneficial bacteria population under field condition [14]. Many PGPRs are known to promote plant growth by a variety of mechanisms: fixation of atmospheric nitrogen that is transferred to the plant, production of siderophores that chelate iron and make it available to the plant root, solubilization of minerals such as phosphorus, and synthesis of phytohormones [12]. PGPR have been reported to directly enhance plant growth by the production of plant growth regulators, and improvements in plant nutrient uptake $[12,16]$ or indirectly by the production of metabolites like antibiotics, siderophores etc that decrease the growth of phytopathogens [12]. PGPRs can be of two different types when associated with host tissue that is endophytes or epiphytes; otherwise they can be even rhizospheric bacteria that are present in the root adhering soil.

The aim of the present study was to isolate and characterize the endophytic bacteria associated to root and stem part of Lycopersicon esculentum, to evaluate different characteristics involved in plant growth promotion. Result revealed that four of the strains showed maximum positive results of PGPR test and its 16SrDNA was amplified and sequenced.

\section{Materials and methods}

\section{Isolation of endophytic bacteria form Lycopersicon esculentum}

Endophytes strains were isolated from root and stem of Lycopersicon esculentum plant (Table 1). Roots and stem part of plant were thoroughly 
washed with sterile n-saline $(0.85 \%)$ and cut down in $1 \mathrm{~cm}$ long pieces through sterile forceps with the help of alcohol. The pieces were transferred to sterile $\mathrm{N}$-agar plate and incubated for $24 \mathrm{hrs}$ at $30^{\circ} \mathrm{C}$.

\section{Morphological and physiological characterization of endophytic isolates}

For the present study, total 18 endophytic bacteria were isolated whose systemic morphological characters done which includes: Size, Shape, Margin, Elevation, Consistency, Opacity, Pigmentation, was done by Systematic Microbiology [3].

Gram's staining bacterial suspension was prepared in sterile distilled water and from this suspension a smear was prepared on clean \& dry glass slide, air dried and then heat fixed. The smear was treated with $1 \%$ crystal violet for $1-2$ min. Gram's iodine was applied for $30 \mathrm{sec}$. to 1 min. Smears were then decolorized with $10 \%$ alcohol. The counter stain, saffranin was then applied for 45-60 seconds. The stained slide were washed with tap water, air dried \& observed under oil immulsion.

For motility test, the culture was inoculated into the Edward's and Ewing motility agar stab medium by stabbing the medium right into the center of agar. The entire depth of the medium was punctured. The medium was incubated at 28 $\pm 2^{\circ} \mathrm{C}$ for $24 \mathrm{hrs}$. After incubation, it was observed for the turbid growth across the line of inoculation, which indicates motile organisms.

For Antibiotic assay, top agar (1.5\%) was prepared and autoclaved. It was cooled to $45^{\circ} \mathrm{C}$, $100 \mu 1$ of culture was added to this and overlaid preset $\mathrm{N}$-agar plates. Using sterile forceps, disc containing the antibiotic of interest was placed on the agar and incubated at $28 \pm 2^{\circ} \mathrm{C}$ for $48 \mathrm{hrs}$.

\section{Estimation of plant growth promoting properties}

(i) Detection of siderophore production: This was performed by a method described by Schwyn and Neilands [27], which involved the use of chrome azurol $\mathrm{S}$ containing indicator plates. Siderophore detection was performed by mixing equal volumes of chrome azurol S (CAS) assay solution and the culture supernatant. Colour change from blue to yellowish orange was indicative of presence of Siderophore. Two percentage of overnight grown culture was inoculated in magnetotactic bacterium Magnetospirillum magneticum AMB-1 (AMB) and grown for $48 \mathrm{hrs}$. Then the culture was centrifuge at $8000 \mathrm{rpm}$ for $20 \mathrm{~min}$ and the supernatant was examined for the presence of siderophore by CAS solution. 


\section{(ii) Evaluation of endophytes for chromium}

tolerance: Isolated strains were tested for resistance to $\mathrm{Cr}$ (VI) by plate dilution method using yeast extract mannitol agar (YEMA) medium. In a plate dilution method, agar plates amended with $\mathrm{K}_{2} \mathrm{Cr}_{2} \mathrm{O}_{7}$ at 50-500 $\mu \mathrm{g} / \mathrm{ml}$ were inoculated with 48 hrs grown cultures and incubated at $28 \pm 2{ }^{\circ} \mathrm{C}$ for $72 \mathrm{hrs}$. The lowest concentration of $\mathrm{Cr}$ (VI) inhibiting on YEMA plates was defined as minimum inhibitory concentration [35].

(iii) Phosphate solubilization ability: The phosphate solubilizing ability of the cultures were examined by growing the cultures on Pikovskaya's agar plate and looking for the zone of clearance after incubating at $28 \pm 2{ }^{\circ} \mathrm{C}$ for 48 $72 \mathrm{~h}$.

(iv) Antifungal activity: The spores of fungal cultures (Fusarium oxysporium, Alternaria,, Trichoderma and Rhizoctonia solani) grown on Potato dextrose agar (PDA) blocks were placed in the centre of PDA plates and the bacterial cultures were streaked at four ends of the plate. This was incubated at $28 \pm 2^{\circ} \mathrm{C}$ for $48-96 \mathrm{hrs}$ and examined for zone of growth inhibition.

(v) Protease production: It is indicated by casein degradation, which was determined by observing clearing zones in Nutrient casein agar plate. All isolated culture was streak on Nutrient casein agar plate and incubated at $28 \pm 2{ }^{\circ} \mathrm{C}$ for 24-48 hrs. Next day flood the plate with Frazier's reagent to detect clear zone around the colony.

(vi) Indole 3-acetic acid (IAA) production test: IAA in presence of $\mathrm{FeCl}_{3}$ develops pink color. This fact is utilized in determination of IAA. Different mineral acids like hydrochloric acid, perchloric acid, phosphoric acid, nitric acid and sulphuric acid can be used to develop the color. $\mathrm{FeCl}_{3}-\mathrm{HClO}_{4}$ reagent is the most sensitive and shows least interference by other iodole compounds like, tryptophan, skatole, acetyletryptamine etc.

Loopful of each culture was inoculated in luria broth (LB) $2 \mathrm{ml}$ containing $50 \mu \mathrm{g} / \mathrm{ml}$ tryptophan and incubated at $28^{\circ} \mathrm{C}$ for $24 \mathrm{hrs}$ on shaking condition, centrifuged at $9000 \mathrm{rpm}$ for $15 \mathrm{~min}$, $2 \mathrm{ml}$ of supernatant was taken in fresh tube and 2-3 drops of orthophosphoric acid was added. A quantity of $4 \mathrm{ml}$ of reagent $\left(1 \mathrm{ml}\right.$ of $0.5 \mathrm{M} \mathrm{FeCl}_{3}$ in $50 \mathrm{ml}$ of $35 \% \mathrm{HClO}_{4}$ ) was added to this aliquot and incubated for $25 \mathrm{~min}$ at $\mathrm{RT}$. Absorbance was measured at $530 \mathrm{~nm}$. Auxin quantification values were recorded by preparing standard calibration curve made by using IAA standard in the range of $10-100 \mu \mathrm{g} / \mathrm{ml}$. IAA stock solution was prepared as $100 \mu \mathrm{g} / \mathrm{ml}$ in $50 \%$ ethanol. Standard graph of IAA concentration was plotted against O.D 530 and 
the concentration of IAA in samples used was calculated.

Organic acid production: It was studied by growing the cultures in Calcium carbonate agar plate and observing for a clear zone around the colony.

Chitinase production: It was observed by spotting the culture on chitin agar plate and observing zone of clearance after incubating at $28 \pm 2^{\circ} \mathrm{C}$ for $48-72 \mathrm{~h}$. Chitinase activity (degradation of $\beta$ - 1,4- N- acetylglucosamine polumer) were tested in a minimal medium. There were clear zones were detected after 5 days incubation period at $30^{\circ} \mathrm{C}$.

Pectinase production: It was detected by spotting the culture on pectin agar plate and observing zone of clearance after incubating at $28 \pm 2{ }^{\circ} \mathrm{C}$ for $48-72 \mathrm{~h}$.

\section{S-rDNA sequencing of PGPR isolates}

Well isolated colonies (2-3 colonies) of the culture whose 16S-rDNA had to be amplified were suspended in $20 \mu 1-30 \mu l$ of sterile distilled water. The suspension was heated at $95^{\circ} \mathrm{C}$ for 20 min and centrifuged at $9000 \mathrm{rpm}$ for $1 \mathrm{~min}$. The supernatant was used as template DNA in the PCR system [26]. The 16S-rDNA gene fragment was amplified using universal eubacterial full- length primers. The amount of DNA taken for amplification was 10ng.

\section{Primer sequences}

Forward Primer (PF) 5' AGA GTT TGA TCC TGG CTC AG 3' Reverse Primer (PR 5' ACG GCT ACC TTG TTA CGA CTT 3'

The PCR components and conditions (to set a system of $30 \mu \mathrm{l})$ used for amplification. Amplifications were performed in Eppendroff gradient thermal cyclers programmed for 30cycles. The PCR thermal cycle consist of an initial denaturation step of $3 \mathrm{~min}$ at $94^{\circ} \mathrm{C}$, Then $30 \mathrm{sec}$ at $94^{\circ} \mathrm{C}$ for denaturation, $30 \mathrm{sec}$ at $57^{\circ} \mathrm{C}$ for primer annealing and in last step primer extension done by $2 \mathrm{~min}$ at $72^{\circ} \mathrm{C}$. Steps $2,3,4$ repeated for 30 cycles followed by a final extension of $10 \mathrm{~min}$ at $72^{\circ} \mathrm{C}$. The amplified products were then examined by an aliquot of the DNA $(2 \mu \mathrm{l})$ was analyzed on a $1.0 \%$ agarose gel along with $500 \mathrm{bp}$ ladder and stained with ethidium bromide $(0.5 \mu \mathrm{g} / \mathrm{ml})$. The gels were visualized under UV light in a transilluminator and photographed subsequently.

Sequence Analysis: The product was sequenced and matched with the already available sequences in the Gene Bank by uploading the obtained sequence in its FASTA format in nucleotide sequence match available at the online tool of RDP Database Project II. 


\section{Results and discussion}

\section{Isolation of endophytic bacteria}

We have isolated endophytic bacteria from the Lycopersicon esculentum (tomato) plants from different field areas on the Nutrient agar (NA) medium. Colonies showing different morphological characteristics on the Nutrient agar plates were selected for further characterization. About 18 strains were isolated. The number of isolates, the source of their plant and field from where the samples were procured are mentioned in the Table 1.

Table1: Bacterial endophytes isolates form Lycopersicon esculentum

\begin{tabular}{|c|c|c|c|}
\hline Sample & Location & $\begin{array}{l}\text { No. of } \\
\text { isolate } \\
\text { s }\end{array}$ & $\begin{array}{l}\text { Name of the } \\
\text { isolates }\end{array}$ \\
\hline 1 & $\begin{array}{l}\text { AAU } \\
\text { (Anand) }\end{array}$ & 5 & $\begin{array}{l}\text { HR } 1 \\
\text { HR } 2 \\
\text { HR } 3 \\
\text { HR } 4 \\
\text { HR } 5\end{array}$ \\
\hline 2 & $\begin{array}{l}\text { Mansa } \\
\text { (Gandhina } \\
\text { gar) }\end{array}$ & 7 & $\begin{array}{l}\text { HR } 6 \\
\text { HR } 7 \\
\text { HR } 8 \\
\text { HR 9 } \\
\text { HR } 10 \\
\text { HR } 11 \\
\text { HR } 12 \\
\end{array}$ \\
\hline 3 & $\begin{array}{l}\text { Gana } \\
\text { (Anand) }\end{array}$ & 6 & $\begin{array}{l}\text { HR } 13 \\
\text { HR } 14 \\
\text { HR } 15 \\
\text { HR } 16 \\
\text { HR } 17 \\
\text { HR } 18\end{array}$ \\
\hline
\end{tabular}

\section{Morphological and physiological}

\section{Characterization}

In this work all the 18 isolates strains were picked on the basis of different morphological characteristics. The morphological characteristics of the final four short-listed isolates are shown in Table 2.

\section{Gram's staining and Motility}

Result showed that out of 18 isolates tested 9 were gram negative coccobacilli, 5 were gram positive bacilli and only 4 were gram negative cocci. This indicated that majority $(50 \%)$ of the bacteria in our studies belonged to gram negative coccobacilli strains followed by $22.22 \%$ gram positive bacilli and gram negative cocci seemed to be the most uncommon one constituting only $27.77 \%$ of the total isolates. While in case of motility $66.66 \%$ were motile and remaining $43.44 \%$ were non-motile (Table $3)$.

\section{Antibiotic assay}

The endophytic isolates were also checked for their sensitivity (S) and resistance (R) against antibiotics like Ampicillin, Gentamycin, Spectinomycin, Tetracycline. The result of the antibiotic assay of the rhizospheric isolates is tabulated (Table 4). 
Table 2: Morphologyical and Physiological characteristics of 18 isolates

\begin{tabular}{|c|c|c|c|c|c|c|c|}
\hline $\begin{array}{l}\text { Colony } \\
\text { character }\end{array}$ & Size & Shape & Margin & Elevation & Texture & Opacity & Pigmentation \\
\hline HR1 & Medium & Round & Entire & Raised & Smooth & Transparent & No pigmentation \\
\hline HR2 & Medium & Round & Entire & Flat & Smooth & Transparent & No pigmentation \\
\hline HR3 & Small & Round & Entire & $\begin{array}{l}\text { Slightly } \\
\text { Raised }\end{array}$ & Smooth & Transparent & $\begin{array}{l}\text { Yellow } \\
\text { pigmentation }\end{array}$ \\
\hline HR4 & Small & Round & Entire & $\begin{array}{l}\text { Slightly } \\
\text { Raised }\end{array}$ & Smooth & Opaque & $\begin{array}{l}\text { Yellow } \\
\text { pigmentation }\end{array}$ \\
\hline HR5 & Small & Round & Entire & Flat & Rough & Transparent & No pigmentation \\
\hline HR6 & Small & Round & Entire & $\begin{array}{l}\text { Slightly } \\
\text { Raised }\end{array}$ & Smooth & Transparent & $\begin{array}{l}\text { Yellow } \\
\text { pigmentation }\end{array}$ \\
\hline HR7 & Medium & Round & Entire & Flat & Smooth & Opaque & $\begin{array}{l}\text { Pitch } \\
\text { pigmentation }\end{array}$ \\
\hline HR8 & Medium & Round & Entire & Raised & Smooth & Opaque & $\begin{array}{l}\text { Yellow } \\
\text { pigmentation }\end{array}$ \\
\hline HR9 & Medium & Irregular & Irregular & Flat & Rough & Opaque & $\begin{array}{l}\text { White } \\
\text { pigmentation }\end{array}$ \\
\hline HR10 & Medium & Round & Entire & Flat & Smooth & Transparent & $\begin{array}{l}\text { Yellow } \\
\text { pigmentation }\end{array}$ \\
\hline HR11 & Small & Round & Entire & Raised & Smooth & Transparent & $\begin{array}{l}\text { Yellow } \\
\text { pigmentation }\end{array}$ \\
\hline HR12 & Medium & Irregular & Irregular & Flat & Rough & Opaque & $\begin{array}{l}\text { White } \\
\text { pigmentation }\end{array}$ \\
\hline HR13 & Small & Round & Entire & Flat & Rough & Transparent & No pigmentation \\
\hline HR14 & Medium & Round & Entire & Flat & Smooth & Transparent & $\begin{array}{l}\text { Yellow } \\
\text { pigmentation }\end{array}$ \\
\hline HR15 & Medium & Irregular & Irregular & Flat & Rough & Opaque & $\begin{array}{l}\text { White } \\
\text { pigmentation }\end{array}$ \\
\hline HR16 & Medium & Round & Entire & Flat & Smooth & Transparent & $\begin{array}{l}\text { Yellow } \\
\text { pigmentation }\end{array}$ \\
\hline HR17 & Medium & Irregular & Irregular & Raised & Rough & Transparent & $\begin{array}{l}\text { Golden yellow } \\
\text { pigmentation }\end{array}$ \\
\hline HR18 & Small & Irregular & Irregular & Flat & Rough & Opaque & $\begin{array}{l}\text { White } \\
\text { pigmentation }\end{array}$ \\
\hline
\end{tabular}

\section{Siderophore production}

Assay of siderophore production performed by CAS agar plate method in which following isolates HR1, HR3, HR4, HR7, HR18 showed production of siderophore. So further estimation of siderophore was performed to determine which types of siderophores are produced, either cathecolate or hydroxymates type of sideophore. Unfortunately we could not obtain the result.

\section{IAA production test}

All the isolates were tested for their IAA production. After $24 \mathrm{hrs}$ of incubation with tryptophan all the strains exhibited a significant amount of IAA production. The production of IAA by isolates indicated that the tested strains 
Table 3: The Gram nature and Motility of the 18 isolated strains.

\begin{tabular}{|l|l|l|}
\hline Isolates from Tomato plant & Gram's Nature & Motility \\
\hline HR 1 & Gram -ve cocco bacilli & + \\
\hline HR 2 & Gram -ve cocco bacilli & + \\
\hline HR 3 & Gram -ve cocco bacilli & + \\
\hline HR 4 & Gram -ve cocco bacilli & + \\
\hline HR 5 & Gram -ve cocco bacilli & + \\
\hline HR 6 & Gram -ve cocco bacilli & + \\
\hline HR 7 & Gram -ve cocco bacilli & + \\
\hline HR 8 & Gram -ve cocco bacilli & + \\
\hline HR 9 & Gram -ve cocci & - \\
\hline HR 10 & Gram -ve cocci & - \\
\hline HR 11 & Gram +ve bacilli & + \\
\hline HR 12 & Gram +ve bacilli & - \\
\hline HR 13 & Gram +ve bacilli & + \\
\hline HR 14 & Gram +ve bacilli & - \\
\hline HR 15 & Gram +ve bacilli & - \\
\hline HR 16 & Gram -ve cocci & + \\
\hline HR 17 & Gram - ve cocco bacilli & + \\
\hline HR 18 & Gram -ve cocco bacilli & + \\
\hline
\end{tabular}

$+:$ Indicates motile organism, - : Indicates non-motile organism.

utilized tryptophan as a precursor for growth and produced IAA, the primary auxins in the majority of plant species as a plant growth promoter. Data indicated that all the bacterial endophytes from plant were able to produce IAA in the presence of tryptophan (Table 5). Production of IAA is widespread among bacteria-plant associated. Several bacteria having the ability to anabolise indole-3-acetic acid (IAA) with supplemented L- tryptophan have been isolated from the plant surfaces. Bacterial IAA producers (BIPs) have the potential to interfere with any of these processes by input of IAA into the plant's auxin pool [1]. Patten and Glick [20,21] have shown that bacterial IAA stimulates the development of the root system of the host plant and Brandi and Lindow (1998) have studied the contribution of IAA for bacterial epiphytic fitness, observation supported by the investigation of other workers $[12,20,2,9,33]$.

\section{Chromium tolerance of the endophytic} strains

Almost 17 out of 18 isolates from Lycopersicon esculentum tolerated a chromium concentration upto $500 \mu \mathrm{g} / \mathrm{ml}$. One of the isolate HR11 tolerated upto $300 \mu \mathrm{g} / \mathrm{ml}$, wheres all the isolates showing tolerance above $450 \mu \mathrm{g} / \mathrm{ml}$. There are reports of certain Bacillus spp. tolerating upto 
Table 4: Antibiotic assay of isolated strains

\begin{tabular}{|c|c|c|c|c|}
\hline Isolates & Ampicillin & Streptomycin & Tetracycline & Chloramphenicol \\
\hline HR1 & 10 & 16 & 18 & 23 \\
\hline HR2 & $\mathrm{R}$ & 19 & 13 & 22 \\
\hline HR3 & 14 & 21 & 19 & 24 \\
\hline HR4 & $\mathrm{R}$ & 9 & 15 & $\mathrm{R}$ \\
\hline HR5 & $\mathrm{R}$ & 17 & $\mathrm{R}$ & 14 \\
\hline HR6 & $\mathrm{R}$ & 9 & $\mathrm{R}$ & 13 \\
\hline HR7 & $\mathrm{R}$ & 18 & $\mathrm{R}$ & 17 \\
\hline HR8 & $\mathrm{R}$ & 11 & $\mathrm{R}$ & 8 \\
\hline HR9 & 28 & 29 & 27 & 38 \\
\hline HR10 & $\mathrm{R}$ & $\mathrm{R}$ & 7 & 19 \\
\hline HR11 & 7 & 16 & 18 & 21 \\
\hline HR12 & $\mathrm{R}$ & 13 & 11 & 19 \\
\hline HR13 & $\mathrm{R}$ & $\mathrm{R}$ & 9 & 16 \\
\hline HR14 & 13 & 21 & 15 & 14 \\
\hline HR15 & 8 & $\mathrm{R}$ & 11 & 14 \\
\hline HR16 & $\mathrm{R}$ & $\mathrm{R}$ & 8 & 18 \\
\hline HR17 & $\mathrm{R}$ & 12 & $\mathrm{R}$ & $\mathrm{R}$ \\
\hline HR18 & 21 & 20 & 19 & 24 \\
\hline
\end{tabular}

Resistance microorganism- $\mathbf{R}$, Number mentioned is zone of inhibition in $\mathrm{mm}$

$550 \mu \mathrm{g} / \mathrm{ml}[35]$ and Bacilli spp. is a well known PGPR strain. All the standard strains except $R$. leguminosarum and S. meliloti showed very less tolerance to chromium. Both the strains $R$. leguminosarum and $S$. meliloti are well known for their PGPR activity in leguminous plants. A Rhodococcus erythropolis
MTCC 7905 strain has been shown to be resistant to $300 \mathrm{mg} \mathrm{l}^{-1}$ of $\mathrm{Cr}^{6+}$ isolated from metal contaminated soil samples from a site near Indian Himalayan region has been reported to reduce substantial amounts of $\mathrm{Cr}^{6+}$ to $\mathrm{Cr}^{3+}$ as well as showed to have plant growth promotion of pea (Pisum sativum) in the presence of toxic $\mathrm{Cr}^{6+}$ concentration [30]. 
Table 5: Indole Acetic Acid production by endophytic bacterial isolates

\begin{tabular}{|l|l|}
\hline Isolates & OD at 530nm \\
\hline HR1 & 0.061 \\
\hline HR2 & 0.020 \\
\hline HR3 & 0.050 \\
\hline HR4 & 0.241 \\
\hline HR5 & 0.199 \\
\hline HR6 & 0.067 \\
\hline HR7 & 0.057 \\
\hline HR8 & 0.114 \\
\hline HR9 & 0.056 \\
\hline HR10 & 0.097 \\
\hline HR11 & 0.181 \\
\hline HR12 & 0.007 \\
\hline HR13 & 0.029 \\
\hline HR14 & 0.270 \\
\hline HR15 & 0.112 \\
\hline HR16 & 0.094 \\
\hline HR17 & 0.166 \\
\hline HR18 & 0.079 \\
\hline
\end{tabular}

\section{Phosphate solubilisation}

Phosphorous is one of the most important plant nutrient and a large portion of inorganic phosphate applied to soil as fertilizer is rapidly immobilized [19,24]. Endophytic bacteria possess the capacity to solubilize immobilized mineral phosphates. In this study all the 18 isolates were tested for their phosphate solubilizing activity on Pikovasky agar medium. It was interesting to note that out of 18 endophytic isolates, 8 showed phosphate solubilisation activity (Table 6). Result revealed that majority of the PGPR strains do have phosphate solubilizing activity and such organisms play a major role in plant growth promotion [24].
Table 6: Phosphate Solubilization by endophytic bacterial isolates

\begin{tabular}{|c|l|c|}
\hline Isolate No. & Growth on PV & Zone (mm) \\
\hline HR 1 & Full growth & 20 \\
\hline HR 2 & Full growth & - \\
\hline HR 3 & Full growth & 21 \\
\hline HR 4 & No growth & - \\
\hline HR 5 & No growth & - \\
\hline HR 6 & No growth & - \\
\hline HR 7 & Full growth & 17 \\
\hline HR 8 & No growth & - \\
\hline HR 9 & No growth & 21 \\
\hline HR10 & No growth & - \\
\hline HR 11 & Less growth & 8 \\
\hline HR 12 & Less growth & 11 \\
\hline HR 13 & No growth & - \\
\hline HR 14 & No growth & - \\
\hline HR 15 & No growth & - \\
\hline HR 16 & No growth & - \\
\hline HR17 & Full growth & 31 \\
\hline HR 18 & Less growth & 9 \\
\hline Hm zone of clearance (Pink colour Zone) & Now & - \\
\hline
\end{tabular}

mm zone of clearance (Pink colour Zone)

\section{Organic acid production}

Out of the 8 endophytic isolates showing phosphate solubilization, all 8 showed organic acid production. The isolates number HR7, HR8, HR9, HR10, HR14, HR15 showed slight organic acid production by forming a very thin zone of clearance on the plates of Pikovasky with methyl red as $\mathrm{pH}$ indicator dye. This gave the pink coloured zone that indicated shift in $\mathrm{pH}$ change from alkaline to acidic. Some isolates like HR4, HR7, HR13, HR16 were unable to solubilize phosphate and also did not produce organic acid. This could be because the amount 
of organic acid produced might be very less to do so (Table 7).

\section{Chitinase production}

In the present study none of the strain revealed a clear zone, but 5 isolates out of 18 showed growth on the chitin agar plate, remaining 13 strains did not show any growth (Table 8). Biological control of plant pests and diseases is much more attractive than chemical treatment methods due to its greater specificity and less harmful impact on the environment [34,35]. Major component of fungal cell is chitin. Thus organism having the ability to produce chitinase might have antifungal property.

\section{Pectinase production}

For pectinase production, 17 out of 18 isolates of Lycopersicon esculentum revealed the production of pectinase. The strains showing

Table 7: Isolates showing organic acid production

\begin{tabular}{|c|c|c|c|c|}
\hline Sample No. & Isolate No. & $\begin{array}{l}\text { Production of } \\
\text { Organic acid }\end{array}$ & Zone (mm) & $\begin{array}{l}\text { Pink colour of } \\
\text { Zone }\end{array}$ \\
\hline \multirow{5}{*}{ Sample 1.} & HR 1 & Medium & 13 & +++ \\
\hline & HR 2 & Medium & 10 & ++ \\
\hline & HR 3 & Very less & 8 & ++ \\
\hline & HR 4 & No & - & - \\
\hline & HR 5 & No & - & - \\
\hline \multirow{8}{*}{ Sample 2.} & HR 6 & Very less & 7 & - \\
\hline & HR 7 & Medium & 11 & ++ \\
\hline & HR 8 & Medium & 13 & - \\
\hline & HR 9 & Medium & 10 & - \\
\hline & HR 10 & Very less & 9 & - \\
\hline & HR 11 & Medium & 12 & + \\
\hline & HR 12 & Very less & 8 & ++ \\
\hline & HR 13 & No & - & - \\
\hline \multirow{5}{*}{ Sample 3.} & HR 14 & Medium & 11 & - \\
\hline & HR 15 & Very less & 8 & - \\
\hline & HR 16 & No & - & - \\
\hline & HR 17 & Medium & 11 & +++ \\
\hline & HR 18 & Medium & 13 & + \\
\hline
\end{tabular}

$+: 1.0 \mathrm{~mm}$ ZOC (zone of clearance), ++: $1.2 \mathrm{~mm} \mathrm{ZOC,} \mathrm{+++:} 1.4 \mathrm{~mm} \mathrm{ZOC,} \mathrm{-:} \mathrm{No} \mathrm{zone}$

production of pectinase on pectin agar plate are listed in Table 9. Maximum research indicated that pectin methyl esterase (PME) (EC 3.1.1.11) catalyzes the hydrolysis of methyl-ester groups of cell wall pectins. It has been found in all plant tissues and in some of plant cell wall-degrading microorganisms or insects [5,6] and has been implicated in a number of processes including cell growth [18], fruit ripening [11, 29], abscission and senescence [17], pathogenesis [7] and cambial cell differentiation [13]. 
Table 8: Isolates showing Chitinase production

\begin{tabular}{|c|c|}
\hline Isolates & $\begin{array}{c}\text { Chitinase } \\
\text { Production }\end{array}$ \\
\hline HR1 & - \\
\hline HR2 & + \\
\hline HR3 & - \\
\hline HR4 & + \\
\hline HR5 & - \\
\hline HR6 & - \\
\hline HR7 & - \\
\hline HR8 & - \\
\hline HR9 & - \\
\hline HR10 & - \\
\hline HR11 & - \\
\hline HR12 & - \\
\hline HR13 & + \\
\hline HR14 & - \\
\hline HR15 & - \\
\hline HR16 & - \\
\hline HR17 & + \\
\hline HR18 & positive \\
\hline H : negative
\end{tabular}

Table 9: Isolates showing Pectinase production

\begin{tabular}{|c|c|}
\hline Isolates & $\begin{array}{l}\text { Pectinase } \\
\text { production }\end{array}$ \\
\hline HR1 & + \\
\hline HR2 & + \\
\hline HR3 & + \\
\hline HR4 & + \\
\hline HR5 & + \\
\hline HR6 & + \\
\hline HR7 & + \\
\hline HR8 & + \\
\hline HR9 & + \\
\hline HR10 & + \\
\hline HR11 & + \\
\hline HR12 & + \\
\hline HR13 & + \\
\hline HR14 & + \\
\hline HR15 & + \\
\hline HR16 & - \\
\hline HR17 & + \\
\hline HR18 & + \\
\hline : positive & $-:$ negative \\
\hline
\end{tabular}

16S-rDNA sequencing of PGPR isolates

\section{Colony PCR}

All the plant growth promoting results when compiled together showed one strain (HR7) showed maximum positive features and thus the 16SrDNA of the strain was amplified using universal full length primers. An amplicon of $1.5 \mathrm{~kb}$ was obtained and sent for sequencing to Bangalore Genei, Pvt, Ltd India. The sequence obtained was matched with the online available sequences in RDP (Ribosomal Database Project II) bioinformatics tool.

\section{Multiple sequence alignment phylogenetic analysis}

BLAST (Basic local alignment search tool) search was done for partial 16s rDNA of the isolates HR7 by submitting queries to NCBIBLAST (http://blast.ncbi.nlm.nih.gov/Blast.cgi.) and homologous sequences obtained by standard nucleotide-nucleotide BLAST (blastn) were aligned with the different $16 \mathrm{~s}$ rDNA isolates after sequencing and various related sequence were retrieve after blasting the partial sequence of the isolates obtained after sequencing. Accession No. of the related species was retieved and Multiple sequence alignment (Fig 1) was performed using CLC free protein workbench 5.0. Evolutionary tree for the same 
data was obtained by neighbor joining method with Bootstrap values (expressed as percentages of 100 replications) as shown in (Fig 2). Except HR7 other do not give the sequencing results. Accession no. of some isolates used for multiple alignment with HARDIKSEQ-1(HR7) isolate were, JF423918, JF281099, HQ995502, HQ268732, HQ202541, HQ202540, HQ259948, FM995816, FM995815, FM995811, FM995802, FM995800, FM995798, FM995797, FM995796.

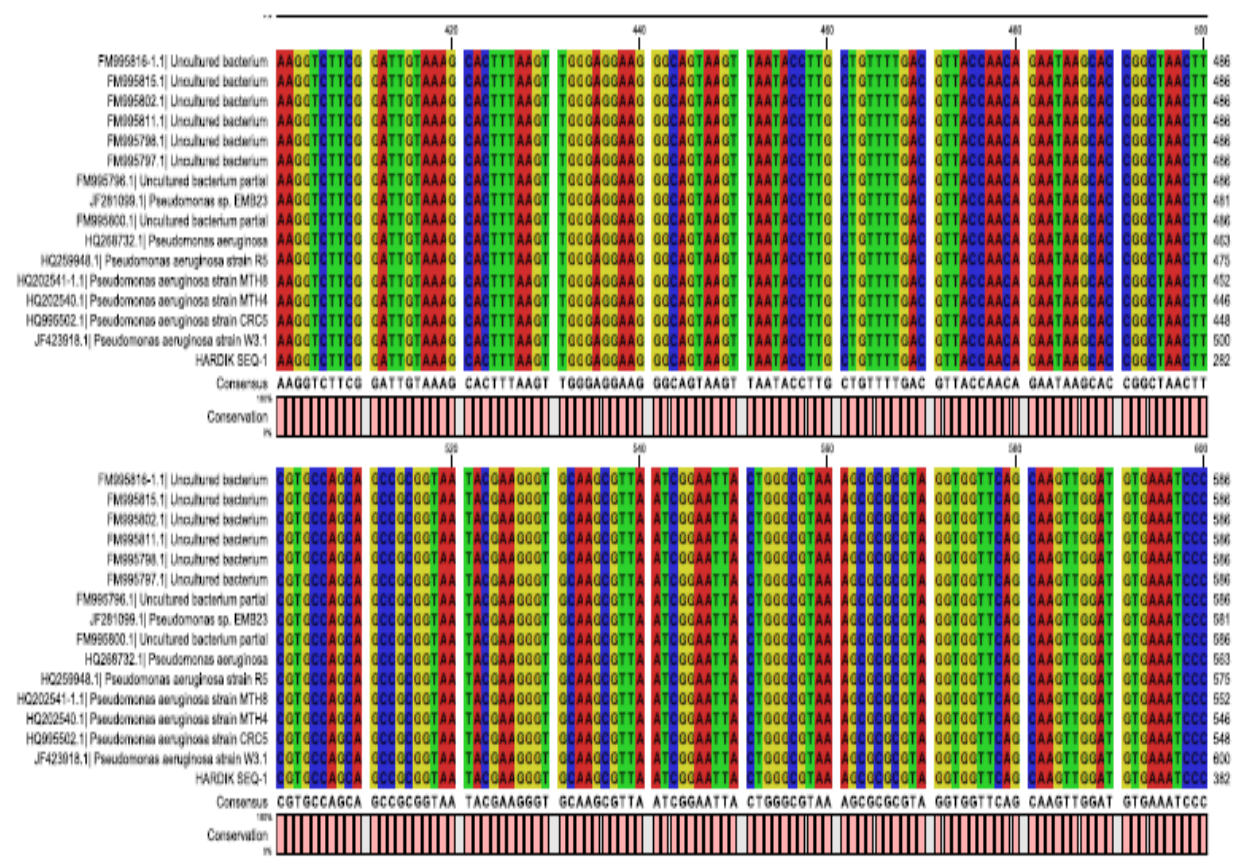

Fig. 1: Multiple sequence alignment for the partial 16s rDNA sequence of hardik seq-1 (HR7) isolate with other related species retrieve after BLAST, resulted in versatile coloring scheme that highlighted the conserved sequence in Aligned sequences.

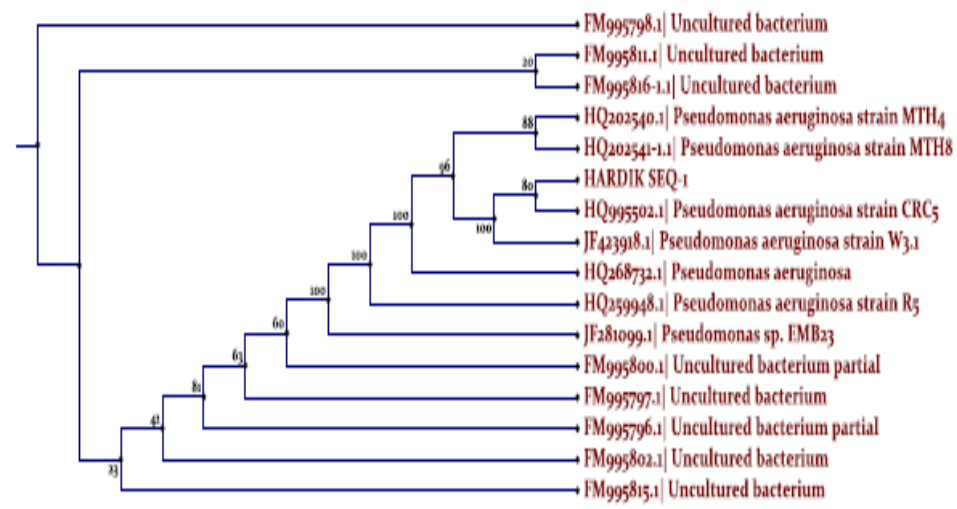

Fig. 2: Phylogenetic tree of partial 16S rRNA genes of Hardik seq-1(HR7) islolates from closely related of resistant bacteria obtained after BLAST. The tree was constructed based on partial $16 \mathrm{~S} r \mathrm{RNA}$ sequences of the isolates and the reference strains. Bootstrap values (expressed as percentages of 100 replications) are shown at branch points. Bootstrap values over $50 \%$ are shown. The scale bar 0.500 indicates $50 \%$ nucleotide sequence substitution 
Precisely, the research concluded that endophytic bacteria isolated form Lycopersicon esculentum produced one or the other different characteristics involved in plant growth promotion. They either produced phytohormones like indole acetic acid, siderophore, protease, pectinase, organic acid showed antifungal activity, chromium tolerance and solubilized phosphate. Only HR7 endophyte of tomato turned out to be Pseudomonas aeruginosa, It is a gram negative coccobacili, sporeforming motile bacilli,which showed maximum PGPR activity. It may be concluded that the above strains may be endophytic and was associated with the plant probably because they may benefit the plant by stimulating its growth.

\section{Acknowledgments}

This research was undertaken with support from the Ashok and Rita Patel Institute of Integrated Study and Research in Biotechnology and Allied Sciences, New Vallabh Vidyanagar (managed by the Charutar Vidya Mandal).

\section{References}

1. Andreae WA, Van Ysselstein MWH: Studies on 3-indole acetic acid metabolism. VI. 3-indole acetic acid uptake and metabolism pea roots and epicotyls. Plant Physiol.1960, 35: 225232.

2. Bastián $\mathrm{F}$, Cohen $\mathrm{A}$, Piccoli $\mathrm{P}$, Luna $\mathrm{V}$, Baraldi and Bottini, V: Production of indole-3-acetic acid and gibberellin A1 and $\mathrm{A} 3$ by Acetobacter diazotrophicus and Herbaspirillum seropedicae in chemically-defined culture media. Plant Growth Regul 1998 24: 7-11.

3. Bergey's Manual of Systematic Bacteriology 2009, 2nd Edition. Published by Springer, New York.

4. Brandi MT, Lindow SE: Contribution of indole-3-acetic acid production to the epiphytic fitness of Erwinia herbicola. Appl Environ Microbiol 1998, 64: 32563263.

5. Campbell BC, Shea PJ: A simple staining technique for assessing feeding damage by Leptoglossus occidentalis Heidemann on cones. Can Entomol 1990, 122: 963968.

6. Christgau S, Kofod LV, Halkier T, Andesen LN, Hockauf M, Dorreich K, Dalboge H, Kauppienen S: Pectin methyl esterase from Aspergillus aculeatus: expression cloning in yeast and characterization of the recombinant enzyme. Biochem. 1996, J. 319:705-712.

7. Collmer A, Keen, NT: The role of pectic enzyme in plant pathogenesis. Annual review of phytopathology 1986, 24:383409.

8. Conrath U: Priming: getting ready for battle. Mol. Plant Microbe Interact 2006, 19: 1062-1071.

9. Dobbelaere S, Croonenborghs A, Thys A, Broek AV, Vanderleyden J: Phytostimulatory effect of Azospirillum 
brasiliense wild type and mutant strains altered in IAA production on wheat. Plant Soil 1999, 212: 155- 164.

10. Downing KJ, Thomson JA: Introduction of the Serratia marcescens chiA gene into an endophytic Pseudomonas fluorescens for the biocontrol of phytopathogenic fungi. Can. J. Microbiol 2000, 46: 363369.

11. Gaffe JD, Tieman M, Handa AK: Pectin methylestrase informs in tomato (Lycopersicon esculentum) tissue: effect of expression of methylestrase antisense gene. Plant Physiol 1994, 105:199-203.

12. Glick BR: The enhancement of plant growth by free living bacteria. Can. J Microbiol 1995, 41: 109-117.

13. Guglielmino N, Liberman M, Catesson AM, Marek A, Prat R, Mutaftschiev S, Goldberg R: Pectin methylesterases from poplar cambium and inner bark: localization, properties and seasonal changes. Planta. 1997, 202: 70-75.

14. Hallmann J, Quadt-Hallmann A, Mahafee WF, Klopper JW: Bacterial endophytes in agricultural crops. Can. J. Microbiol. 1997, 43: 895-914.

15. Henning K, Villforth F: Experimentelle untersuchungen zur frage der bacteriesymbiose in ho“heren pflanzen und ihre beeinflussung durch 'Leitemente'. Biochem. Zeitschr. 1940, 305: 299-309.

16. Kloepper JW: Plant growth promoting rhizobacteria as biological control agents. In: Soil Microbial EcologyApplications in Agricultural and Environmental Management, ed. F. B. Metting, Jr., 1993 pp. 255-274 (Marcel Dekker, Inc., New York).
17. Liners F, Van Custsem P: Distribution of pectic polysaccharides throughout walls of suspension-cultured carrot cells. Protoplasma 1992, 170:10-21.

18. Moustacas AM, Nari J, Borell M, Noat G, Richard J: Pectin metylestarase: metal ions and plant cell wall extention. The role of metal ions in plant cell wall extention. J. Biochem. 1991, 279:351-354.

19. Nautiyal CS, An efficient microbiological growth medium for screening phosphate solubilizing microorganisms. FEMS Microbiol Lett. 1999, 170: 265-270.

20. Patten CL, Glick BR, Bacterial biosynthesis of indole-3-acetic acid. Can. J. microbial 1996, 42: 207-220.

21. Patten CL, Glick BR: Role of Pseudomonas putida indole acetic acid in development of the host plant root system. Appl Environ Microbiol 2002, 68: 3795-3801.

22. Perotti R: On the limits of biological inquiry on soil science. Proc. Int. Soc. Soil Sci 1926, 2:146-161.

23. Reiter B, Pfeifer U, Schwab H, Sessitsch A: Response of endophytic bacterial communities in potato plants to infection with Erwinia carotovora subsp. atroseptica. Appl Environ Microbiol 2002, 68: 2261-2268.

24. Rodriguez H, Fraga R: Phosphate solubilizing bacteria and their role in plant growth promotion. Biotechnol Adv 1999, 17: 319-339.

25. Ryu CM, Kim JW, Choi OH, Park SY, Park SH, Park CS: Nature of a rootassociated Paenibacillus polymyxa from 
field-grown winter barley in Korea. $J$ Microbiol Biotechnol 2005, 15: 984-991.

26. Sambrook J, Russell D W: Molecular cloning: A Laboratory Manual, $3^{\text {rd }}$ edn 2001, Vol.1, Cold Spring Harbor, New York.

27. Schwyn B Neilands JB, Universal chemical assay for the detection and determination of siderophores. Analytical Biochemistry 1987 160: 47-56.

28. Sturz AV, Christie BR, Matheson BG, Arsenault WJ, Buchanan NA, Endophytic bacterial communities in the periderm of potato tubers and their potential to improve resistance to soil-borne plant pathogens. Plant Pathol. 1999, 48:360369.

29. Tieman DM, Handa AK: Reduction in pectin methylesterase activity modifies tissue integrity and action levels in ripening tomato (Lycopersicon esculentum Mill.) fruits. Plant Physiol 1994, 106: 429-436.

30. Trivedi P, Pandey A, Tongmin S: Chromate reducing and plant growth promoting activities of psychhrotrophic Rhodococcus erythropolis MTCC 7905. $J$ Basic Microbiol 2007, 47:513-517.
31. Van Buren AM, Andre C, Ishimaru CA: Biological control of the bacterial ring rot pathogen by endophytic bacteria isolated from potato. Phytopathology 1993, 83: 1406.

32. Van Overbeek L, Van Elsas JD: Effects of plant genotype and growth stage on the structure of bacterial communities associated with potato (Solanum tuberosum L.). FEMS Microbiol Ecol 2008, 64: 283-296.

33. Verma SC, Ladha JK, and Tripathi AK: Evaluation of plant growth promotion and colonization ability of endophytic diazotrophs from deep water rice. $J$ Biotechnol 2001, 91: 127-141.

34. Wang SL, Shih IL, Liang TW, Wang CH: Purification and characterization of two antifungal chitinases extracelluarly produced by Bacillus amyloliquefaciens V656 in a shrimp and crab shell powder medium. J Agric Food Chem 2002, 50: 2241-2248.

35. Wani PA, Khan MS, Zaidi A: Chromium reducing and plant growth promoting Mesorhizobium improves chickpea growth in chromium amended soil. Agron Sustain Dev. 2007, 27: 145-153. 